\title{
A pesca da baleia, uma advertência para o futuro
}

Na sua atual acepção, a conservação da natureza é definida como a utilização pelo homem dos elementos da biosfera, sejam eles animais ou plantas, de tal forma que viabilize o maior benefício para as gerações presentes, garantindo, porém, suas potencialidades para satisfazer as necessidades e aspirações daqueles que nos sucederão no planeta. Em síntese, significa a exploração racional e sensata dos recursos naturais, sem destruí-los em proveito da ganância ou de lucros imediatos. Nesse particular, o relato da história da caça às baleias e de suas conseqüências é um magnífico exemplo do que não deve ser feito, e constitui uma lição para todos aqueles que, detendo alguma parcela de poder decisório, necessitam deliberar sobre o uso das riquezas naturais que recebemos como herança dos antepassados e que temos o dever de transmitir aos nossos descendentes.

Data de tempos imemoriais a caça aos grandes cetáceos, vulgarmente denominados baleias, mas somente nos dois últimos séculos ela assumiu proporções capazes de exaurir os estoques existentes em todos os oceanos. Animais de enorme porte, com crescimento lento e reprodução limitada, nenhuma das baleias jamais existiu em grande número e apenas uma das espécies, o cachalote, parece ter atingido no passado uma população global superior a um milhão de indivíduos.

Mesmo com a utilização de precárias tecnologias de captura - navios à vela, remos e arpões manuais -, ao findar-se o último século, dentre cerca de uma dúzia de espécies de baleias que possuem valor comercial, três já se encontravam fortemente reduzidas em números. Foi, porém, no Século $X X$ que se presenciou o grande massacre. Com o emprego de navios providos de propulsão a vapor ou a diesel, e de arpões explosivos disparados por ca- nhões, aos quais vieram juntar-se todos os recursos da moderna tecnologia - radar, sonar, naviosfábricas e helicópteros - os grandes cetáceos passaram a ser capturados em números crescentes, até atingir-se a absurda cifra de cerca de 66.000 baleias em um só ano, em meados da década de 60 , seguindo-se um inevitável e brusco colapso populacional. No final da mesma década, as populações das diversas espécies subsistiam em números residuais, excetuada apenas uma delas, a pequena baleia minke, cuja pouca rentabilidade comercial a poupara inicialmente do morticínio. A indústria baleei$\mathrm{ra}$, que chegara a mobilizar grandes frotas, indispensáveis à pesca pelágica, por falta de presas entrou em fatal declínio, desativando em larga escala custosos investimentos em navios e instalações. Visando a aliviar vultosos prejuízos, voltou-se então para a exploração de cetáceos menores e menos rentáveis, entre os quais sobressaiu a minke, hoje a única baleia ainda caçada em números expressivos.

A destruição das populações de baleias devida à caça predatória, cujo único objetivo foi maximizar lucros no menor prazo possível, era prevista havia muito tempo. No famoso romance Moby Dick, que retrata a saga dos caçadores de baleias, H. Melville já a previra. No Brasil, José Bonifácio alertava, em 1790, para a prática predatória da caça às baleias, que "trará consigo, a não se prover nisto, a ruína total desta tão importante pescaria".

Em 1946̄, numa tentativa de racionalizar a matança irresponsável, instituiu-se a Comissão Internacional para a Pesca da Baleia - ClB, organização que, por falta de meios coercitivos e por pressão dos países-membros com interesses na indústria baleeira, viu frustrados seus esforços durante a fase mais crítica do extermínio dos grandes cetáceos. Somente em anos recentes, com o apoio da opinião públi- 
ca mundial e de novos países-membros, não-comprometidos com aquela indústria, pôde sua atuação se tornar mais significativa. Em 1982, finalmente, em histórica decisão, foi aprovada a suspensão total da caça comercial de todas as baleias a partir de 1986, por um período de cinco anos.

No Brasil, a captura comercial de cetáceos, iniciada em 1602, nunca teve expressão econômica realmente importante, mas contribuiu de forma significativa para o extermínio das populações locais de algumas espécies. Inicialmente muito abundantes em nossa costa, a ponto de haver referências, em documentos do Século XVIII, à "'imensidade de baleias... nas entradas e barras dos rios e nas baías" e às "horríveis baleias" na Guanabara, foram elas dizimadas pelos baleeiros com base nas numerosas estações costeiras de captura, então denominadas "armações", termo que se perpetuou no topônimo correspondente, tão comum ao longo de nosso litoral. No início do Século XX, a pesca da baleia sobrevivia no país como atividade irrelevante, até que, a partir de meados do século, a associação com capitais japoneses veio revitalizá-la, tornando-a uma indústria de algum vulto nos estados do Rio de Janeiro e da Paraíba. O Japão, país em que perdura arraigada tradição de captura de cetáceos e consumo de seus produtos, já se tornara um dos maiores devastadores das populações remanescentes. Cerceado em suas atividades pelo sistema de cotas, estabelecidas pela CIB para cada país, como medida de conservação das espécies exploradas comercialmente, passaram os japoneses a contornar tais limitações, associando-se a outros países, de cujas cotas de captura ainda se utilizam em proveito próprio.

A indústria nipo-brasileira instalada em Cabo Frio, RJ, teve efêmera duração, por falta de economicidades decorrente da drástica rarefação de suas presas. Nos mares da Paraíba, contudo, área de acasalamento de cetáceos, principalmente da minke, as capturas mostraram-se rentáveis e, dadas as peculiaridades ecológicas da área, continuarão a sê-lo enquanto não forem exterminados completamente os estoques sobreviventes.

A crítica situação das baleias, devastadas e reduzidas a poucos milhares de exemplares, e a difusão das idéias conservacionistas em todo o mundo, decorrência da compreensão tardia de que a humanidade está a saquear os recursos naturais do planeta, motivaram um forte movimento da opinião pública mundial em defesa dos últimos grandes cetáceos. Simultaneamente, no Brasil, os conservacionistas agiam ativamente, procurando convencer as autoridades brasileiras a proibir as capturas no Nordeste.

Lamentavelmente, a ganância, os interesses comerciais da indústria nipo-brasileira e as injunções políticas locais mostraram-se mais poderosos do que os argumentos conservacionistas. Em 1979, o governo brasileiro chegou a determinar a cessação da pesca, mas recuou pouco depois, sob alegações pouco convincentes de necessidade de defesa dos interesses sociais. Essa atitude refletiu-se no voto contrário do Brasil, por ocasião da votação na CIB, a que nos referimos antes. A atitude insegura de nosso país quanto ao assunto se patenteia pelo fato de, após votar contra a suspensão da pesca, não ter apresentado objeção formal àquela decisão, atitude que, de acordo com a regulamentação da Comissão, Ihe isentaria de acatá-la. Poder-se-ia imaginar que, afinal, passáramos a adotar uma atitude sensata e conservacionista de proteção aos últimos grandes cetáceos. Contudo, a ilusão se desfez quando pouco depois, na Conferência dos Países-Membros da CIB sobre o Comércio Internacional das Espécies da Flora e Fauna Selvagens em Perigo de Extincão - CITES, ocorrida em Botswana, em abril de 1983, o Brasil voltou a juntar-se ao Japão, Peru e URSS, em seu voto contrário à inclusão de algumas espécies de baleias, entre elas a minke, no Apêndice I da Convenção, o que significa severas restrições para o comércio de tais espécies. Apesar desses quatro votos contrários, a inclusão foi aprovada por esmagadora maioria. Testemunhamos assim, em âmbito internacional, a continuação da política indecisa, sinuosa e anticonservacionista de nosso país, com considerável desgaste de sua imagem e em proveito exclusivo de uma atividade comercial pouco expressiva, reconhecidamente predatória e condenada pela opinião pública mundial.

O ocaso da indústria baleeira, conseqüência da exaustão de um recurso natural que, se corretamente gerido, poderia constituir-se em benefício perene para a humanidade, é um ensinamento sobre o qual necessitamos meditar. Inúmeros outros elementos da biosfera sofreram ou estão sofrendo os efeitos da exploração predatória e, se medidas adequadas não forem adotadas a tempo, repetirão o destino das baleias. Em nosso país, as portentosas florestas dos estados da Região Sul, com infinitas possibilidades de utilização duradoura, foram quase totalmente eliminadas, sem recuperação possível. Voltamo-nos agora para a Amazônia, a renovar nela os mesmos desatinos. Nossa fauna está em grande parte exaurida, devastada pela eliminação de habitats naturais e pela caça ilegal; e há quem ainda defenda sua exploração comercial. Nossa natureza, sofrida, castigada em todas as suas manifestações, demonstra o descaso com que os recursos naturais e a defesa de sua perenidade têm sido encarados, em nome de um desenvolvimento que se tornou um fim em si mesmo, em detrimento de seu único e verdadeiro objetivo - o bem-estar do homem. 